\title{
THE ROLE OF CUSTOMER ATTITUDE IN MEDIATING KNOWLEDGE INFLUENCE TOWARDS THE PURCHASE INTENTION OF GREEN PRODUCT
}

\author{
AA. Sagung Ayu Wulandari, I Ketut Rahyuda, Ni Nyoman Kerti Yasa ${ }^{\bowtie}$ \\ Faculty of Economics and Business, Udayana University, Bali, Indonesia
}

Info Artikel

Sejarah Artikel:

Diterima Juni 2015

Disetujui Juli 2015

Diterbitkan September 2015

Keywords:

Green Marketing;

Green Product;

Consumer Knowledge;

Attitude On The Environment;

Purchase Intention

\begin{abstract}
Protecting the environment has become a main idea for some modern companies in applying the green marketing strategy. Many consumers perceive that a product with natural raw material can give a better benefit both in terms of health issue and environment. The purpose of this study is to find out the role of attitude in mediating consumer knowledge influence towards the purchase intention of green product Ever-E 250 in Denpasar.The samples were 110 respondents from all over Denpasar taken with the purposive sampling method and path analysis. The result of the study shows that consumer knowledge has significant and positive influence towards the attitude and purchase intention of green product Ever-E 250. The attitude variable has been proven to be able to mediate consumer knowledge influence towards the purchase intention of green product Ever-E 250 in Denpasar significantly, while the mediation happen is partial, so that the attitude variable functions as a mediator of consumer knowledge influence towards the purchase intention of green product.
\end{abstract}

\section{PERAN SIKAP MEMEDIASI PENGARUH PENGETAHUAN KONSUMEN TERHADAP NIAT BELI PRODUK HIJAU}

\begin{abstract}
Abstrak
Perlindungan terhadap lingkungan telah menjadi ide utama untuk beberapa perusahaan modern dalam menerapkan strategi pemasaran hijau. Banyak konsumen merasa bahwa produk dengan bahan baku alami dapat memberikan manfaat yang lebih baik dari segi kesehatan dan lingkungan. Tujuan dari penelitian ini adalah untuk mengetahui peran sikap dalam memediasi pengetahuan konsumen yang berpengaruh terhadap niat pembelian produk hijau Ever-E 250 di Denpasar. Jumlah sampel dalam penelitian ini adalah 110 responden dari seluruh Denpasar diambil dengan metode purposive sampling dan analisis jalur. Hasil penelitian menunjukkan bahwa pengetahuan konsumen memiliki pengaruh yang signifikan dan positif terhadap sikap dan niat pembelian produk hijau Ever-E 250. Variabel sikap telah terbukti dapat memediasi pengetahuan konsumen yang berpengaruh terhadap niat pembelian produk hijau Ever-E 250 di Denpasar secara signifikan, sedangkan mediasi yang terjadi adalah parsial, sehingga variable sikap berfungsi sebagai mediator pengetahuan konsumen yang berpengaruh terhadap niat pembelian produk hijau.
\end{abstract}

JEL Classification: M3, M31 


\section{INTRODUCTION}

Indonesia is a country with abundant natural capital. However, the consumptive life style of its people forces them to do unfriendly actions toward the environment. This finally leads to a mindset change in which people now believe that every activity should consider any effects toward the environment. Protecting the environment then becomes the main idea for some modern companies in implementing the green marketing strategy. Manongko (2011) state that green marketing is defined as an effort of an organization or company in designing products' promotion, price, and distribution which is environmentally friendly, so that the products produced and distributed should be through a green process which means the raw material and other supporting materials are all environmentally friendly.

Healthy lifestyle has become a positive motivation for the society in improving their quality of life. According to Ali (2011), Waksito and Harsono (2012) many consumers perceive that a product with the natural raw material will give better benefit for their health. Every consumer has different decision-making pattern that will influence their attitudes in purchasing a product. The decision in purchasing a product is underlain on the purchase intention that arises in the consumer's mind. Hansudoh (2012) defines purchase intention as desirability to buy which is a part of the process to the purchasing action done by a consumer. Another definition is given by Kotller (2008) which states that purchase intention is the consumer attitude that arises as a response to the object showing his desirability to do purchasing.

A previous study conducted by Putri and Suparna (2014) states that among various green products circulated in the market, a supplement namely Ever-E 250 is one of the products dominating the market that is more popular and interesting for the society in Denpasar. In Wijaya (2014), it is stated that consumer's knowledge and attitude can predict the purchasing attitude so that it is important for a marketer to understand the relationship between consumer's knowledge and attitude toward their attitudes in buying a product. According to Suprapti (2010), consumer attitude is an expression of someone's feeling which reflects his likes and dislikes toward an object. Someone's attitude is the result of a psychological process so that it cannot be observed directly but should be concluded from what is said and what is done. Based on the background explained above, then this study aims to find out how the influence of consumer knowledge towards the purchase intention of green product Ever-E 250 mediated with attitude in Denpasar is

\section{Green Product}

According to Durifet al. (2010), green products are usually durable, non-toxic, made from recycled materials, or packaged minimally. Green products are produced, distributed and consumed to reduce the effects of environmental damage. Therefore, green products have no adverse impact on the environment and do not harm human health. Manongko (2011) defines green products as products that are not harmful to humans and the environment, not wasteful of resources, do not produce excessive waste and do not involve cruelty to animals.

\section{Attitude}

Suprapti (2010) defines consumer attitudes as an expression of one's feelings that reflect the like or dislike toward an object. A person's attitude is the result of a psychological process then it cannot be observed directly but must be inferred from what is said and done. Definition of attitude mostly used is that proposed by Allport that attitude is a learned predisposition to respond to a particular object or group of objects in a way that is pleasant or unpleasant consistently. 


\section{Consumer Knowledge}

QaderandZainudin (2011) defineorganic knowledge as the ability of consumers to identify some concepts related to green products through information possessed by consumers. In analogy to the theory of green products marketing, consumers who have a high knowledge of the environment are likely to have the motivation to buy green products. Consumers who are aware of the importance of the consequences of consumption will encourage the purchase of organic food. Organic knowledge plays to stimulate consumer attitudes toward organic products positively. Another opinion of Laroche et al. (2001) says that knowledge is a source of information for individuals which plays to consider the consumption of organic food, so that organic knowledge influences the consumers' evaluation of the organic food.

\section{Green Marketing}

Manongko (2011) defines green marketing as an effort of the organization in designing promotion, price and distribution of products that do not harm the environment. Green marketing covers many aspects before the products manufactured are offered to consumers as a green product. Another term that is often equated with green marketing is environmental marketing. According to Situmorang (2011), green marketing has been widely accepted by several companies as a competitive strategy that is appropriate. The green term is often used interchangeably with the word "pro-environmental" or proenvironment. Many companies are committed to do green marketing in their marketing communication which aims to achieve greater market share, the growing market of consumers who care about the environment.

\section{Purchase Intention of Green Product}

According to Hansudoh (2012), purchase intention is interpreted as a desire to buy, which is part of the process of moving towards the actions of purchases made by a consumer. Before purchasing, consumers begin to gather product information based on personal experience and the external environment. The purchase intention of green products is conceptualized as a possible willingness of a person in interest to consume products that have environmentally friendly features compared to other products (Rashid, 2009).

\section{Hypothesis 1 and 2}

Jayanti et al. (2013) expressed that the attitude adopted by consumers today is the result of consumer's previous experience and knowledge. The study showed that if consumers already have some knowledge about the environment, then this knowledge will build their positive attitudes. It is also supported by the findings of Noor et al. (2012) which state that consumers who have a high environmental knowledge will have a more positive attitude towards the environment.

Laroche et al. (2001) state that consumers who have an organic knowledge believe that by consuming organic foods, they will get better benefits so that consumers will have the intention to buy organic products in the market. Previous research by the Putri and Suparna (2014) also stated that a demographic variable, one of which contains consumer knowledge about the environment has a strong influence on purchase intentions. Consumers who have extensive knowledge on environmental issues are proved to have a high intention to purchase green products. Based on such review, the hypothesis can be formulated as follows:

H1: Consumer knowledge has positive and significant effects toward the attitudes to the environment.

$\mathrm{H} 2$ : Consumer knowledge has positive and significant effects toward the purchase intention of green product Ever-E 250.

\section{Hypothesis 3}

Attitude has positive correlation toward the purchase of the green product. This fact is supported in the finding by Cheah and Phau (2011) who state that consumer with favorable attitude than the unfavorable attitude towards 
the environment are more likely to purchase products that are environmentally friendly. The study done by Chan and Lau (2000) mentions that there are three antecedents namely eco literacy, interpersonal influence and value orientation, which have a strong correlation with attitudes towards green products. A consumer with a favorable attitude towards environmentally friendly products is more likely to buy green products. Hamid et al. (2012) also stated that he considered if the consumer has the attitude it will cause ecological awareness of green products. They will buy these products and even be prepared to pay higher cost for the perceived benefits. Based on the above review, the hypothesis can be formulated as follows:

H3: Attitude toward environment positively and significantly influence the intention of purchasing green product Ever-E 250

\section{Hypothesis 4}

Noor et al. (2012) state that broader knowledge can change someone's attitude. They found that the influence of the attitude towards the environment was obtained stronger for consumers with a high level of environmental knowledge than consumers with a low level of environmental knowledge. It is also found in the study by Yeoh and Paladino (2008) which states that the attitude of partially mediate the relationship between knowledge of the environment with green product purchasing behavior. They found there was the full mediating effect of attitude towards the relationship between environmental concerns with green product purchasing attitude. It is also disclosed by Aman et al. (2012) which states that the attitude will affect or mediate consumers' intention to buy green products by having environmental knowledge. Based on the above review, the hypothesis can be formulated as follows:

H4: Attitude mediates the effect of consumer knowledge towards consumers' intention of purchasing green products Ever-E 250 significantly

The newest trend in marketing known as "Green Marketing" is inseparable from the presence of consumers who have extensive knowledge and a positive attitude towards the environment. Based framework and hypotheses of the study, the research model can be described in Figure 1.

\section{METHOD}

This research uses an associative method which taken the location in Denpasar because this city had the most population in Bali where the majority of people are modern enough and considered for having broad and positive behavior toward the environment.

Research population in this study is general consumers in Denpasar that consume or recognize various brands of supplements unless

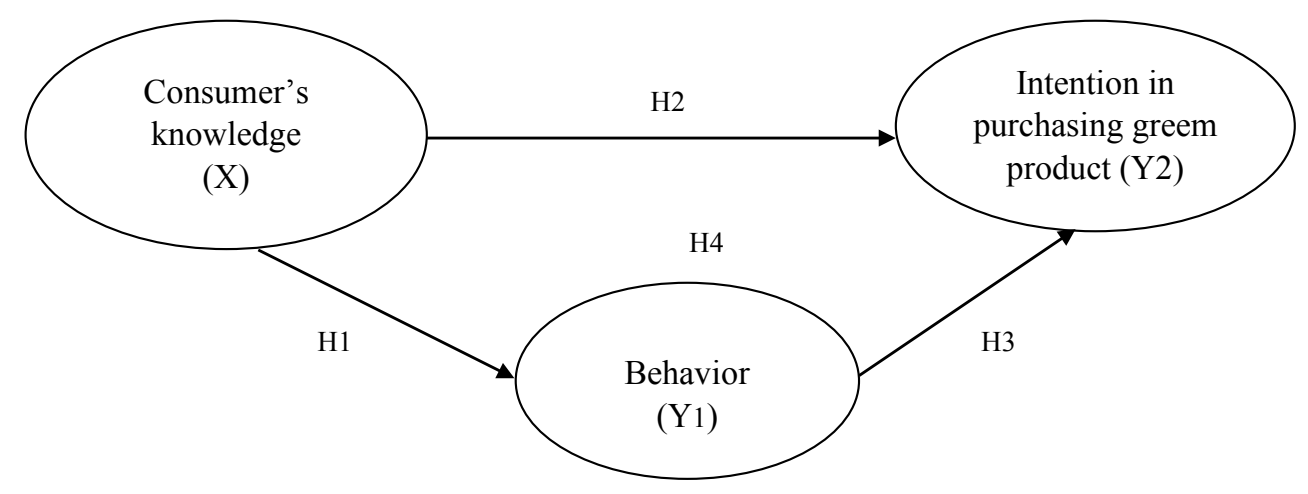

Figure 1. Research Model 
AA. Sagung Ayu Wulandari, dkk / The Role Of Attitude In Mediating Consumer...

the consumer of green supplements under the brand Ever-E 250. This study used a nonprobability sampling technique, with purposive sampling method which means sampling technique with a certain consideration. The criteria used in selecting the sample namely: 1) People who live in the city of Denpasar, 2) Know the green supplement products brand Ever-E 250, 3) Never consume green supplement products brand Ever-E 250.

Data gathering is done through research using questionnaire which being distributed directly to respondents to be answered themselves. Questionnaire is the technique of data collection carried out by providing a set of questions or statements to respondents and will be measured using the measurement scale in the form of semantic differential (scale differences of meaning). Semantic differential scale aims to measure the difference in the meaning of the respondents' attitudes towards an object in a meaningful way (Garland, 1990).

Semantic differential scale arranged in a continuum line that answers "very positive" it is located on the right lines and answers "very negative" is located on the left side of the line or vice versa. Respondents can give an answer in the range of a positive answer to the negative. It depends on the perception of the respondents who are being assessed. This study used a technique path analysis which is an extension of the multiple linear regression analysis that is useful to assess causal relationships between variables.

Table 1. Respondents' Characteristics

\begin{tabular}{|c|c|c|c|c|}
\hline No. & Variables & Classifications & Total (people) & Percentage \\
\hline \multirow{3}{*}{1} & \multirow{3}{*}{ Gender } & Male & 49 & 44,54 \\
\hline & & Female & 61 & 55,46 \\
\hline & & Total & 110 & 100 \\
\hline \multirow{5}{*}{2} & \multirow{5}{*}{ Ages (year) } & $\leq 20$ & 17 & 15,46 \\
\hline & & $21-31$ & 54 & 49,09 \\
\hline & & $32-42$ & 36 & 32,72 \\
\hline & & $43-53$ & 3 & 2,73 \\
\hline & & Total & 110 & 100 \\
\hline \multirow{6}{*}{3} & \multirow{6}{*}{$\begin{array}{l}\text { Education His- } \\
\text { tory }\end{array}$} & Senior High School & 43 & 39,09 \\
\hline & & Diploma & 24 & 21,82 \\
\hline & & Bachelor & 41 & 37,27 \\
\hline & & Master & 2 & 1,82 \\
\hline & & Doctorate & 0 & 0 \\
\hline & & Total & 110 & 100 \\
\hline \multirow{6}{*}{4} & \multirow{5}{*}{ Jobs } & Student & 37 & 33,64 \\
\hline & & Civil Worker & 21 & 19,09 \\
\hline & & Entrepreneur & 16 & 14,55 \\
\hline & & Private company empoyee & 35 & 31,82 \\
\hline & & Other & 1 & 0,90 \\
\hline & \multicolumn{2}{|r|}{ Total } & 110 & 100 \\
\hline
\end{tabular}

Source: data processed (2014) 


\section{RESULT AND DISCUSSIONS}

There were 110 respondents in this study who described by presenting characteristics based on demographic variables namely gender, age, education history and work. Table 1 shows that respondents are dominated by female as many $44,54 \%$. This indicates that most respondents who have a desire to buy green supplement brand Ever-E 250 are women. Based on age classification, these results show that respondents are at range of aged $\leq 20$ years is equal to $15.46 \%$ of respondents; aged $21-31$ years is equal to $49.09 \%$ of respondents ; aged $32-42$ years is equal to $32.72 \%$, and the last aged $43-53$ is equal to $2.73 \%$.

Based on the latest educational classification of this study indicating that the majority of respondents are a group of respondents from high school education level that is equal to $39.09 \%$, followed by education level diploma in the amount of $21.82 \%$, education level bachelor degree is equal to $37.27 \%$, and the rest that by $1.82 \%$ with the educational level of master. Based on the final classification is a classification based on the work that is dominated by the students in the amount of $33.64 \%$, followed by civil servants in the amount of $19.09 \%, 14.55 \%$ are self-employed, private sector employees which amounted to $31.82 \%$, and the other is equal to $0,90 \%$.

\section{Test of Instruments Validity}

Validity test in each question item is using item analysis such as correlation of each item's scores with the entire scores. Correlation between the score of an item with the total score of the item is then compared with $r$ critical. If the item correlation to total score is greater than the critical $r(0.30)$, the instrument is said to be valid. Table 2 shows that all the statements in the variable indicator of consumer knowledge, attitudes, and intentions to buy green products have a Pearson correlation greater than 0.30, so that all the indicators are fulfilling the data validity and can be declared valid.

\section{Reliability Test of the Instruments}

Reliability testing of each question or statement in the research instrument used Cronbach's Alpha method. The instrument is said to be reliable to measure the variables if it is

Tabel 2. Test of Instruments Validity

\begin{tabular}{cccc}
\hline Variables & Instruments & Pearson Correlation & Valid or Invalid \\
\hline \multirow{2}{*}{ Consumer's knowl- } & $\mathrm{X} .1$ & 0,579 & Valid \\
edge & $\mathrm{X} .2$ & 0,686 & Valid \\
(X) & $\mathrm{X} .3$ & 0,753 & Valid \\
& $\mathrm{X} .4$ & 0,574 & Valid \\
\hline \multirow{3}{*}{ Attitude (Y1) } & Y1.1 & 0,802 & Valid \\
& Y1.2 & 0,855 & Valid \\
& Y1.3 & 0,598 & Valid \\
\hline
\end{tabular}

Source: data processed (2014)

Table 3. Reliability Test Result

\begin{tabular}{lll}
\hline Variable & Cronbach's Alpha & Note \\
\hline Consumer's Knowledge $(\mathrm{X})$ & 0,753 & Reliable \\
Attitude(Y1) & 0,807 & Reliable \\
The Intention to purchase green products (Y2) & 0,801 & Reliable \\
\hline
\end{tabular}

Source: data processed (2014) 
AA. Sagung Ayu Wulandari, dkk / The Role Of Attitude In Mediating Consumer...

above 0.60 . Table 3 shows that all three research instruments namely the variables of consumer's knowledge, attitudes and the intention to purchase green products have the Cronbach's Alpha coeffecient which is bigger than 0.60 . Therefore, all the statements meet the criteria to be a reliable instrument.

\section{Result Analysis}

The evaluation of the overall model is done through path analysis which is the extension of the linear regression analysis that is useful to assess the causal relationship among variables through software SPSS 17.0. The result of path analysis can be seen in the following Table 4.

Based on the result of substructure path analysis as shown in the Table 4, the structural equation is as follows:

$$
\begin{aligned}
\mathrm{Y} 1 & =\beta 1 \mathrm{X}+\mathrm{e}_{1} \\
\mathrm{Y} 1 & =0,831 \mathrm{X}+\mathrm{e}_{1}
\end{aligned}
$$

Based on the analysis substructure path 2 as shown in Table 5, the structural equation is as follows:

$$
\begin{aligned}
& \mathrm{Y} 2=\beta 2 \mathrm{X}+\beta 3 \mathrm{Y} 1+\mathrm{e} 2 \\
& \mathrm{Y} 2=0,446 \mathrm{X}+0,324 \mathrm{Y} 1+\mathrm{e} 2
\end{aligned}
$$

Based on the model of the substructure 1 and 2 , the final path of diagram model can be arranged. Before drawing up a model diagram of the final path, the value of the standard error is calculated as follows:

$$
\begin{aligned}
& e=\sqrt{ }\left(1-R_{1}^{2}\right. \\
& \beta 1=\sqrt{ }\left(1-R_{1}^{2}=\sqrt{ } 1-0,690=0,556\right. \\
& \beta 2=\sqrt{ }\left(1-R_{2}^{2}=\sqrt{ } 1-0,544=0,675\right.
\end{aligned}
$$

\begin{tabular}{|c|c|c|c|c|c|c|}
\hline & & \multicolumn{2}{|c|}{ Unstandardized Coefficients } & \multicolumn{3}{|c|}{ Standardized Coefficients } \\
\hline \multicolumn{2}{|c|}{ Model } & $\mathrm{B}$ & Std. Error & Beta & $\mathrm{T}$ & Sig. \\
\hline \multicolumn{2}{|c|}{ (Constant) } & 2,374 & 0,677 & & 3,509 & 0,001 \\
\hline \multicolumn{2}{|c|}{ Pengetahuan Konsumen } & 0,613 & 0,040 & 0,831 & 15,506 & 0,000 \\
\hline $\mathrm{R}^{2}$ & :0,687 & & & & & \\
\hline F Value & : 240,447 & & & & & \\
\hline Sig. F & $: 0,000$ & & & & & \\
\hline
\end{tabular}

Based on the calculation of the influence of the error (e), it is obtained the influence

\begin{tabular}{|c|c|c|c|c|c|}
\hline \multirow[b]{2}{*}{ Model } & \multicolumn{2}{|c|}{ Unstandardized Coefficients } & \multirow{2}{*}{$\begin{array}{c}\text { Standardized Coefficients } \\
\text { Beta } \\
\end{array}$} & \multirow[b]{2}{*}{$\mathbf{T}$} & \multirow[b]{2}{*}{ Sig. } \\
\hline & $\mathbf{B}$ & Std. Error & & & \\
\hline \multirow{3}{*}{$\begin{array}{l}\text { (Constant) } \\
\text { Attitude of consumer } \\
\text { knowledge }\end{array}$} & 4,681 & 1,090 & & 4,295 & 0,000 \\
\hline & 0,411 & 0,108 & 0,446 & 3,800 & 0.000 \\
\hline & 0,405 & 0,147 & 0,324 & 2,761 & 0,007 \\
\hline$: 0,535$ & & & & & \\
\hline F Statistic $: 63,704$ & & & & & \\
\hline Sig. F $\quad: 0,000$ & & & & & \\
\hline
\end{tabular}
result of error $\left(\beta_{1}\right)$ of 0,556 and the influence of error $\left(\beta_{2}\right)$ of 0.675 .

Table 4. The Result of Linear Regression Analysis 1

Source: data processed (2014)

Table 5. The Result of Linear Regression Path Analysis 2

Source: data processed (2014) 


$$
\begin{aligned}
\mathrm{R}_{\mathrm{m}}^{2} & =1-\left(\beta_{1}\right)^{2}\left(\beta_{2}\right)^{2} \\
& =1-(0,556)^{2}(0,675)^{2} \\
& =1-(0,309)(0,455) \\
& =1-0,140=0,86
\end{aligned}
$$

Total determination value is 0.86 . It means that $86 \%$ variation of green product purchase intentions are influenced by the variations in consumer's knowledge and attitudes, while the remaining $14 \%$ is affected by other factors which are not included in the model. So Therefore, the results of the research path coefficients can be illustrated in Figure 2.

Based on the path diagram in Figure 2, are used to determine the influence of direct, indirect influence and total influence between variables. Calculation of influence between variables are summarized in the following table.

\section{Test of the Hypothesis}

The Influence of consumer's knowledge on the attitudes to the environment

H0: There is no effect on the attitudes of consumer's knowledge on the environment

H1: Consumer knowledge has positive and significant effects toward the attitudes to the environment.

Based on the analysis of the influence of consumer's knowledge on the attitude, it is obtained Sig.t of 0.000 with the beta coeffecient value of 0.831 . Sig. $t 0.000<0.05$ indicates that the $\mathrm{HO}$ is rejected and $\mathrm{H} 1$ is accepted. This result means that the consumer's knowledge and significant positively and significantly affects towards the environment.

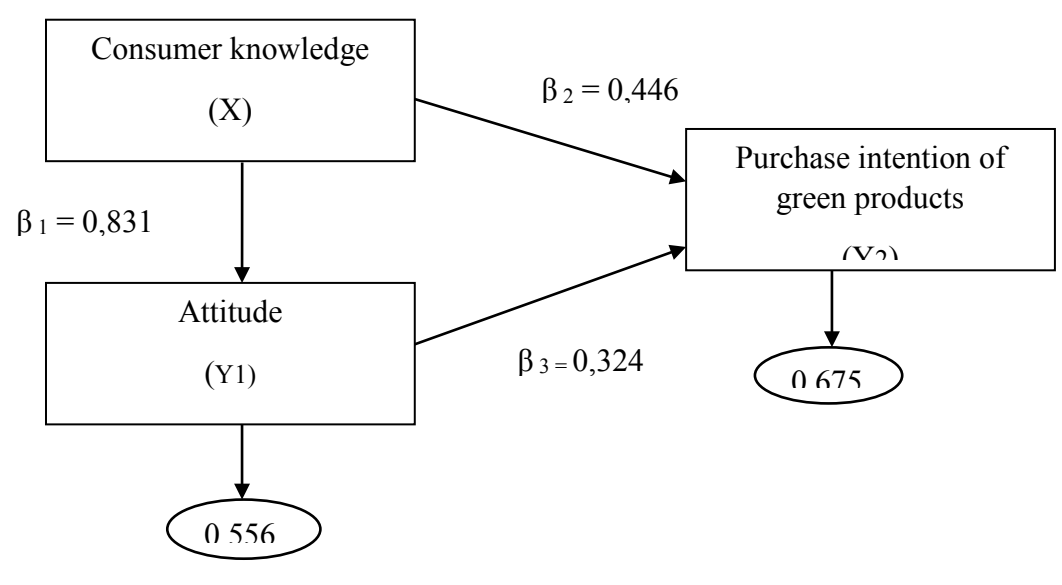

\begin{tabular}{|c|c|c|c|}
\hline The Effect of Variable & Direct Effect & $\begin{array}{l}\text { Indirect Effe t Through Attitude } \\
(\text { (Y1) }(\boldsymbol{\beta} 1 \times \beta 3)\end{array}$ & Total Effect \\
\hline $\mathrm{X} \rightarrow \mathrm{Y}_{1}$ & 0,831 & - & 0,831 \\
\hline $\mathrm{X} \rightarrow \mathrm{Y}_{2}^{1}$ & 0,446 & 0,269 & 0,715 \\
\hline $\mathrm{Y}_{1} \rightarrow \mathrm{Y}_{2}$ & 0,324 & - & 0,324 \\
\hline
\end{tabular}

Figure 2. The Validation of Model Diagram of The Final Path

Table 6. Direct Effect, Indirect Effect and the Total Effects of Consumer Knowledge (X), Attitude (Y1), and Intention of Purchasing Green Products (Y2)

Source: data processed (2014) 
AA. Sagung Ayu Wulandari, dkk / The Role Of Attitude In Mediating Consumer...

The Influence of consumer's knowledge on the intention of purchasing green products brand Ever-E 250

H0: There is no effect of consumer knowledge on the intention of purchasing green products of the brand Ever-E 250

$\mathrm{H} 1$ : Consumer knowledge has positive and significant effects toward the purchase intention of green product Ever-E 250

Based on the analysis of the influence of consumer's knowledge of consumer purchase intentions green products obtained value Sig. $\mathrm{t}$ of 0.000 to 0.446 beta coefficient. Sig. $t 0.000$ $<0.05$ indicates that the $\mathrm{HO}$ is rejected and $\mathrm{H} 1$ accepted. This result means that the consumer knowledge and significant positive effect on the intention to buy green products brand Ever-E 250.

The Influence of attitudes towards green products purchase intention of the brand named Ever-E 250:

H0: There is no influence of attitude towards the intention of buying green products named Ever-E 250.

H1: Attitude toward environment positively and significantly influence the intention of purchasing green product Ever-E 250.

Based on the results of the analysis of the effect of attitudes towards green products purchase intention of the brand Ever-E 250, it is obtained the Sig. $t$ of 0.007 with the beta coeffecient 0.324 beta coefficient. Sig. $t 0.007$ $<0.05$ indicates the attitude that $\mathrm{HO}$ is rejected and $\mathrm{H} 1$ is accepted. This result means that the attitude positively and significantly impact on the intention to buy green products brand Ever-E 250.

\section{Test of Hypothesis for the role of Mediation}

Test of mediation variable is done by using Sobel test which is an analytical tool to test the significance of an indirect relationship between the dependent and independent variables which are mediated by the mediator variable. Sobel test can be calculated by using Microsoft Excel 2007. If the calculating value of the $\mathrm{Z}$ value is greater than 1.96 (with a 95\% confidence level), it means that the mediator variable mediates significantly the relationship between the dependent variable and independent variables. Based on the equation that has been formulated through Microsoft Excel 2007 calculation, the Sobel Test results in this study is as follows:

$$
\begin{aligned}
& Z=\frac{0,446 \cdot 0,405)}{\sqrt{0,405^{2} 0,108^{2}+0,446^{2} 0,147^{2}+0,108^{2} 0,147^{2}}} \\
& Z=0,18063 / 0,0803965 \\
& Z=2,2467
\end{aligned}
$$

Tabel 7. Result of Sobel

\begin{tabular}{ll}
\hline Z Value & Sig \\
\hline 2,2467 & 0,000 \\
\hline
\end{tabular}

Table 7 shows that the tabulation of $\mathrm{Z}=$ $2.2467>1.96$ with a significance level of 0.000 $<0.05$ which means the mediator variables which is the attitude is assessed to be significant in mediating the relationship between consumer's knowledge of the intention of purchasing green products brand Ever-E 250.

\section{ConsumerKnowledgeInfluencetowardsEnvi- ronment Attitude}

The Hypothesis testing on consumer knowledge influence towards environment had positive influence from consumer knowledge variable toward the environment attitude with result of (Sig. $t \leq 0,05$ ) and the beta coefficient of 0,831 shows that the consumer knowledge positively influence the significance towards environmental attitude. It means that the more consumer knowledge the more positively of consumer attitude toward environment. As the finding result of Jayanti et al. (2013) showed that the attitude which is followed by consumer is the result of consumer experience and knowledge before. The attitude was 
formed from direct contact with the object attitude. Based on the arise attitude, the consumer will decide their perception on environment damage level that can influence their desire to buy and pay more to the green product.

\section{Consumer knowledge Influence towards the Purchase Intention of Green Product Ever-E 250}

The hypothesis testing on consumer knowledge influence toward purchase intention of green product Ever-E 250 got positive effect from the variable of consumer knowledge purchase intention with the result of ( Sig. $t \leq$ $0,05)$ and the coefficient beta of 0,446 shows that the consumer knowledge has positive effect towards purchase intention of green product. It means the more consumer knowledge the more purchase intention of green product in market. It is in line with finding of Wahid et al. (2011), stated that there is a positive relation between consumer knowledge and the attitude of purchasing green product. The same investigation was found by Putri and Suparna (2014) they stated that demography variable which is one of them in the consumer knowledge on environment has powerful influence toward purchasing intention.

\section{AttitudeinfluencetowardPurchaseintention of green product Ever-E 250}

The hypothesis testing on attitude influence toward purchase intention of green product Ever-E 250 got positive effect from the attitude variables of purchase intention of green product with the result of ( Sig. $t \leq$ $0,05)$ and the beta coefficient of 0,324 that shows environment attitude has positive and significant effect toward the purcahse intention of green product. It is in line with the result finding of Cheah and Phau (2011) and Hamid et al. (2012), which stated that consumer with benefit attitude toward environment has positive and significant relation toward purchase intention of eco-friendly product. If the consumer has ecological attitude, it will make awareness toward the green product, so they will buy and pay more for the beneficial effect that they got. Based on the result, the hypothesis of attitude influence toward purchase intention is accepted.

\section{The Role of Attitude in Mediating Consumer KnowledgeInfluencetowardPurchaseIntenti- on of green product Ever-E 250}

The hypothesis testing on the role of attitude in mediating consumer knowledge influence toward purchase intention of green product Ever-E 250 using Sobel Test found the attitude affected significantly to mediate consumer knowledge toward purchase intention of green product Ever-E 250 with the tabulation result of $Z=2,2467>1,96$ with significant level of $0,000<0,05$. It means that the consumer knowledge will make positive attitude toward environment so from the arising attitude will influence or mediate the consumer intention to buy green product. It is in line with the research finding of Yeoh and Paladino (2008) which stated that mediating attitude is a part of the relation between environmental knowledge and the purchasing attitude of green product. It is because the wide knowledge will change perception and consumer attitude toward product especially green product which is distributed in market. Based on the result, the hypothesis of the role of mediating attitude of consumer knowledge influence toward purchase intention of green product is accepted.

\section{CONCLUSION}

The limitation of this research can be concluded as follows: (1) the scope of research is limited so the result of research cannot be generalized for consumer of green product outside Denpasar; (2) the used of supplement product Ever-E 250 as the green product which is used in this research is less emphasized, so it makes the product tends to less specific and (3) 
AA. Sagung Ayu Wulandari, dkk / The Role Of Attitude In Mediating Consumer...

this result is conducted in current time (cross section) However, the situation can change (dynamist), which causes less importance to be conducted in the future.

The result of the research is expected to be useful for management of PT. Konimex as the producer of green supplement Ever-E 250 to promote intensively so it can strengthen the position of vitamin E supplement product especially Ever-E250 as the supplement which is eco-friendly and give positive effect to consumer skin and body health. Based on the result, it is obtained that environmental attitude will affect consumer intention to buy green product. The positive attitude toward environment will give big effect to the existence of green product in the market. It can be concluded that it can be essential factor in developing the purchase intention of green product.

Based on analysis and discussion in this investigation, it can be concluded as follows: (1) The consumer knowledge has positive and significant effect toward environment attitude. It means the more consumer knowledge has positive influence toward the environment attitude; (2) the consumer knowledge has positive and significant effect towards the attitude and purchase intention of green product Ever-E 250 in Denpasar. It means the more consumer knowledge will affect the purchase intention of green product, especially green supplement product Ever-E 250; (3) The attitude has positive and significant effect toward purchase intention of green product Ever-E 250 in Denpasar. It means the more positive attitude of consumer toward the environment the more purchase intention of green product especially green supplement product Ever-E 250 and (4) the ability to mediate consumer affect knowledge towards the purchase intention of green product Ever-E 250 in Denpasar significantly, while the mediation happen in this research is partial, means the attitude variable has functions as a mediator of consumer knowledge influence towards the purchase intention of green product Ever-E 250. Because it is partial, so without attitude influence, the consumer knowledge still has positive and significant toward purchase intention of green product Ever-E 250

Based on the conclusion, it can be obtained some suggestion as follows: (1) The high consumer knowledge and attitude on environment can be a potential market for konimex management for promoting green supplement product. It is important for the manager of konimex to improve the intensity of telling the ecological benefit in green supplement product Ever-E 250; (2) the konimex management need a marketing strategy of green supplement product Ever-E 250 on the target market by promoting female consumers in teenage level and adult level as the potential consumers; (3) It is needed to consider the used of green product which is more specific so it can be one of reference for future research to investigate others green product which is more famous in general community and (4) Take the broader scope of region for example take the location in Bali or Indonesia and also wide target of respondent especially for female consumers of teenager and adult level.

\section{REFERENCES}

Ali, S. 2011. Prediksi Perilaku Ramah Lingkungan yang Dipengaruhi Oleh Nilai dan Gaya Hidup Konsumen. Jurnal Perspektif Bisnis. 11 (1): 113-125.

Aman, A. H., Lizawati., A. H \& Hussein, Z. 2012. The Influence of Environmental Knowledge and Concern on Green Purchase Intention The Role of Attitude as a Mediating Variable. British Journal of Arts and Social Sciences. 7 (2): 145-167.

Chan, R. Y. K \& Lau, L. B. Y. 2000. Antecedents of Green Purchases: a Survey in China. Journal of Consumer Marketing. 17 (4): 338-357.

Cheah, I \& Phau, I. 2011. Attitudes Towards Environmentally Friendly Products The Influence of Ecoliteracy, Interpersonal Influence and Value Orientation. Marketing Intelligence \& Planning. 29 (5): 452-472.

Durif, F., Boivin, C \& Julien, C. 2010. In Search Of a Green Product Definition. Innovative Marketing. 6 (1): 25-33. 
Hamid, S. A. R, Ghafoor, H. A \& Shah, T. Z. 2012. Analysis Of Attitude Towards Green Purchase: Pakistan in Context. International Journal of Business and Social Science. 3 (6): 112-115.

Hansudoh, S. A. 2012. Pengaruh Celebrity Endorsement Terhadap Purchase Intention Melalui Perceived Value Pada Produk Top Coffe di Surabaya. E-Journal Universitas Katolik Widya Mandala Surabaya. 1 (5):1-7.

Jayanti, N. D., Kumadji, S \& Yaningwati, F. 2013. Analisis Faktor-faktor yang Mempengaruhi Green Purchasing. Universitas Brawijaya Malang. 1-7.

Kottler, P \& Keller, K. L (Bob Sabra, MM. Penerjemah). 2008. Manajemen Pemasaran. Edisi 13. Jakarta: Erlangga.

Laroche, M., Bergeron, J \& Barbaro, F. G. 2001. Targeting Consumers Who Are Willing to Pay More for Environmentally Friendly Products. Journal of Consumer Marketing. 18 (6): 503-520.

Manongko, A. A. C. H. 2011. Green Marketing dan Pengaruhnya Terhadap Keputusan Pembelian Melalui Minat Membeli Produk Organik. Universitas Brawijaya Malang. 3-37.

Noor, A. M. N., Muhammad, A., Kassim, C. Z., Jamil, N. M., Mat, N. M \& Salleh, H. S. 2012. Creating Green Consumers: How Environmental Knowledge and Environmental Attitude Lead To Green Purchase Behaviour?. International Journal of Arts \& Sciences. 5 (1): 55-71.

Osgood, 1975 in Garland, Ron. 1990. A Comparison of Three Forms of The Semantic Differentia. Marketing Bulletin. 1 (4): 19-24.

Putri, Y \& Suparna, G. 2014. Peran Kebiasaan Membaca Label Dalam Memediasi Pengaruh Variabel Demografi Terhadap Niat Membeli
Produk Hijau Merek Nature-E di Kota Denpasar. Fakultas Ekonomi dan Bisnis, Universitas Udayana. 975-986.

Qader, I. K \& Zainudin, Y. 2011. The Impact of Media Exposure on Intention to Purchase Green Electronic Products Amongst Lecturers. International Journal of Business and Management. 6 (3): 240-248.

Rashid, N. A. 2009. Awareness of Eco-label in Malaysia's Green Marketing Initiativ. International Journal of Business and Management. 4 (8):10.

Situmorang, J. R. 2011. Pemasaran Hijau yang Semakin Menjadi Kebutuhan Dalam Dunia Bisnis. Jurnal Administrasi Bisnis. 7 (2):131-142.

Southey, G. 2011. The Theories of Reasoned Action and Planned Behavior Applied to Business Decisions: a Selective Annotated Bibliography. Journal of New Business Ideas \& Trends. 9 (1): 43-50.

Suprapti, N. S. A. 2010. Perilaku Konsumen Pemahaman Dasar dan Aplikasinya Dalam Strategi Pemasaran. Denpasar: Udayana University Press.

Wahid, N. A., Rahbar, E \& Shyan, T. S. 2011. Factors Influencing the Green Purchase Behavior of Penang Environmental Volunteers. International Business Management. 5 (1):38-49.

Waksito, J \& Harsono, M. 2012. Green Consumer: Diskripsi Tingkat Kesadaran dan Kepedulian Masyarakat Joglosemar terhadap Kelestarian Lingkungan. Jurnal Dinamika Manajemen. 3(1).

Wijaya, T. 2014. Nilai dan Pengetahuan Sebagai Prediktor Intensi Beli Makanan Organik. Jurnal Manajemen dan Kewirausahaan. 16 (1

Yeoh, M \& Paladino, A. 2008. Analysing the Effects of Prestige of Environmental Attitudes and Behaviours upon Low-involvement Purchase. ANZMAC. 2066-2071. 